\title{
Multi-annual climate in Parque Nacional Pan de Azúcar, Atacama Desert, Chile
}

\author{
Clima multianual en el Parque Nacional Pan de Azúcar, Desierto de Atacama, Chile
}

MATTHEW V. THOMPSON ${ }^{1, *}$, BEATRIZ PALMA ${ }^{2}$, JASON T. KNOWLES ${ }^{3} \&$ N. MICHELE HOLBROOK ${ }^{1}$

\author{
${ }^{1}$ Biological Laboratories, Department of Organismic and Evolutionary Biology, \\ Harvard University, Cambridge, Massachusetts, 02138, USA \\ ${ }^{2}$ Facultad de Ciencias Agropecuarias y Forestales, Universidad de Las Américas, Providencia, Santiago, Chile \\ ${ }^{3}$ City of Huntington Beach, Public Works Department, GIS, Huntington Beach, California, 92648, USA \\ *Author for correspondence
}

\begin{abstract}
The lomas formations of the Peruvian and Atacama deserts are characterized by both climatic and floristic spatial heterogeneity, as well as non-contiguous pockets of relatively distinct flora. We examined two distinct types of communities in Parque Nacional Pan de Azúcar in Chile, the low-elevation arroyo and bajada community, and the high-elevation fog-zone community. We determined the distribution with elevation of the dominant perennial plant species in a single arroyo community, as well as the distribution of associated climatic characteristics. Climatic conditions (including air temperature, relative humidity, and wind speed and direction) were recorded from June, 1999, to March, 2001, for the arroyo, as well as for a medium-elevation inland site with little vegetation, and a high-elevation fog-zone site with copious vegetation. The fog layer, or camanchaca, derived from the marine inversion layer ubiquitous to the Peruvian and Atacama deserts was found to be more persistent, though weaker, during the summer months and somewhat more condensed and shallower in the winter months, with uncharacteristically dry air and high temperatures occurring at and above $400 \mathrm{~m}$ elevation during the late fall and early winter of 2000. The reduction or increase in the maximum elevation of the camanchaca or a change in the rainfall regime of the park may have broad implications for the distribution or even presence of certain species in Parque Nacional Pan de Azúcar. Vegetation patterns appear to be strongly dependent on inversion layer development, and perhaps on its subsidence during the winter. A number of species prevalent at low-elevation sites may have little advantage at a highelevation foggy site, whereas the consistently high humidity at low elevations would be a boon to any desert plant accustomed to low precipitation. If we are to successfully assess the effects of changes in southern Pacific weather patterns, it will become necessary to more closely examine the local variation in climate and plant distribution in these regions, on sets of species with known distributions and in environments whose climatic conditions are particularly well-characterized.
\end{abstract}

Key words: Pan de Azúcar, meteorology, plant, distribution.

\section{RESUMEN}

Las "lomas", formaciones de los desiertos Peruano y de Atacama, se caracterizan por su heterogeneidad climática y florística, así como también por la discontinuidad de una vegetación relativamente distintiva y particular. Se investigaron dos grupos distintos de comunidades vegetales en el Parque Nacional Pan de Azúcar en Chile, las comunidades de baja elevación "arroyo" y "bajada", y la comunidad de la zona de niebla a mayor elevación. Se determinó la distribución altitudinal de las especies de plantas perennes dominantes en un arroyo, así como la distribución de las características climáticas asociadas. Las variables climáticas (incluyendo la temperatura ambiental, la humedad relativa, y la velocidad y dirección del aire) fueron registradas desde el mes de junio de 1999 hasta marzo de 2001, en el arroyo, así como en un sitio de elevación media en el interior del parque con poca vegetación y en otro sitio de alta elevación y vegetación abundante en la zona de niebla. El nivel de niebla, o camanchaca, derivada de la inversión marítima omnipresente en los desiertos Peruano y de Atacama, fue más persistente, aunque más débil, durante los meses de verano, y algo mas condensada y superficial durante los meses de invierno, con aire inusualmente seco y caliente sobre los $400 \mathrm{~m}$ durante el final del otoño e inicios del invierno de 2000. La reducción o el incremento en la elevación máxima de la camanchaca o un cambio en el régimen de precipitación podría tener grandes implicaciones en la distribución o aun más sobre la presencia de ciertas especies en el Parque. El patrón de distribución de las plantas parece ser fuertemente dependiente del desarrollo de la inversión marítima, y posiblemente de su descenso durante el invierno. Algunas especies comunes en sitios de baja elevación podrían tener poca ventaja en sitios altos y nublados, mientras que la alta humedad en los arroyos daría gran ventaja a cualquier planta desértica acostumbrada a la escasez de lluvias. Si quisiéramos discutir exitosamente los efectos de los cambios en los patrones climáticos del Pacifico Sur, sería necesario examinar cuidadosamente la variación climática local asociada a la distribución de la vegetación in estas regiones, considerando especies de distribución bien conocida y en ambientes cuyas condiciones climáticas estén particularmente bien caracterizadas.

Palabras clave: Pan de Azúcar, meteorología, planta, distribución. 


\section{INTRODUCTION}

The lomas formations, or coastal, high-topography, fog-zone desert communities found between sea level and the top of the fog zone, characteristic of the coastal Atacama and Peruvian deserts, are the home to numerous endemic plants and are under extensive floristic study (Dillon \& Hoffmann 1997). Of particular biogeographical and conservation interest is the possibility that climate change, or specific changes in the El Niño Southern Oscillation (ENSO), could significantly alter the distribution of plants in the lomas communities (Dillon \& Rundel 1989, Tago-Nakazawa $\&$ Dillon 1999). Due to their high spatial heterogeneity and high beta diversity, the potential impacts of climate change on these communities can only be assessed locally and phenomenologically.

In much of the Atacama desert of Chile, climate is severe ( $<10 \mathrm{~mm}$ rain per year, on average), and nutrient and water cycles curtailed, to the extent that the life cycles and physiological behavior of plant life are closely tied to the small-scale spatial and temporal variation in micro-climate (Ehleringer et al. 1992, Evans \& Ehleringer 1994, Ehleringer et al. 1998). Parque Nacional Pan de Azúcar, of the Second and Third regions in northern Chile, houses a number of sub-habitats in lomas formations, each with its own floristic qualities (see Johnston 1929, Rundel et al. 1991, Rundel et al. 1996), largely defined by distance from the coast and elevation with respect to the marine inversion-derived fog layer, or camanchaca. To explore the potential effects of climate change on these communities, we focused on the distribution of the dominant perennial plant species in a single coastal quebrada community, and the climate of the sites in which they are found.

In this paper, we present results from five meteorological stations established in Parque Nacional Pan de Azúcar (from 210 to $800 \mathrm{~m}$ elevation) for over a year (June, 1999, to March, 2001). We discuss the general and seasonal climate of the park, as well as the spatial distribution of climate within Quebrada Agua Salada (our primary study site, Fig. 1) and among other sites, and present a discussion of the distribution of plants with elevation and the floristic differences between low and high-elevation communities.

\section{MATERIAL AND METHODS}

\section{Study site}

The climate of the Chilean-Peruvian coastal desert is characterized by the following features
(Trewartha 1981): high, uniform atmospheric humidity; low annual temperatures with little variability; strong but shallow trade winds; a strongly prevalent stratus deck; and brief periods of relatively heavy rainfall and high temperatures. The critical oceanic and continental characteristics that build these features are the cool Humboldt current, which brings water from highlatitude southern waters; the divergence of this current from the coastline due to the Coriolis effect, in turn leading to an upwelling of cold, deep-ocean water via Ekman drift; the anti-cyclone off the coast of western South America, which brings dry air to the region via subsidence from the subtropical jet; and the Andes, which dramatically increase the positional stability of the anti-cyclone. The result is a strong temperature inversion layer, which results in a thick stratus layer, high humidity, and low, stable temperatures. Air masses below the inversion layer, due to their high humidity, are negatively buoyant, preventing convection and precipitation.

In Pan de Azúcar National Park, Chile (2553' to $26^{\circ} 15^{\prime} \mathrm{S}, 70^{\circ} 29^{\prime}$ to $70^{\circ} 40^{\prime} \mathrm{W}$ ), as in other localities along the Chilean coast, broad marine terraces, composed of Cretaceous sediments (limestone and sandstone), overhang the coastline, feeding the shoreline with a rocky effluent of large boulders and coarse gravel. Against these terraces, the marine inversion layer forms a thick stratus layer, the camanchaca, between approximately 300 and $800 \mathrm{~m}$ that supports not only a broad array of plant life, but important fauna, as well. The camanchaca seldom reaches and therefore has little effect on the fluvial channels interspersed along the coastline and among the terraces, where relative humidity rarely reaches saturation. In the interior desert, plant life is limited to sites of salt-water intrusion (aguadas) or to areas of concentrated runoff (arroyos). Dense vegetation does not resume until the foothills of the Andes. For more information on the floristic and general climatological characteristics of the lomas formations of northern Chile, see Rundel et al. (1991), Rundel et al. (1996), and Dillon \& Hoffmann (1997).

The distribution of resident plant communities within Pan de Azúcar is heterogeneous and strongly influenced by small scale variation in climatic and edaphic conditions (Rundel et al. 1991, Rundel et al. 1996). Rainfall, though relatively uniform within the park, becomes concentrated locally in arroyos and bajadas (open communities along the major drainage routes in the park, and steep, rocky rainfall channels, respectively). Records available from 1913 to the present, either from within the park, or from 
meteorological stations in the nearby towns of Taltal $\left(25^{\circ} 26^{\prime} \mathrm{S}, 70^{\circ} 35^{\prime} \mathrm{W}\right)$ and Chañaral $\left(26^{\circ} 21^{\prime}\right.$ ' $\mathrm{S}, 70^{\circ} 42^{\prime} \mathrm{W}$ ), indicate strong interannual variation in precipitation. A best-estimate record of precipitation for the park at large has been assembled using data from 1913 to 1925 from Taltal (Almeyda 1948), 1926 to 1980 from Chañaral
(Hajek \& di Castri 1975), 1981 to 1996 from Chañaral (Dirección Meteorologica de Chile, Aeropuerto Arturo Merino Benítez, Pudahuel, Santiago), and 1997 to 2000 from a pluviometer installed at Caleta Pan de Azúcar (CONAF) in the park. Plants growing below the fog zone $(<300 \mathrm{~m}$ elevation) receive little if any atmospheric mois-
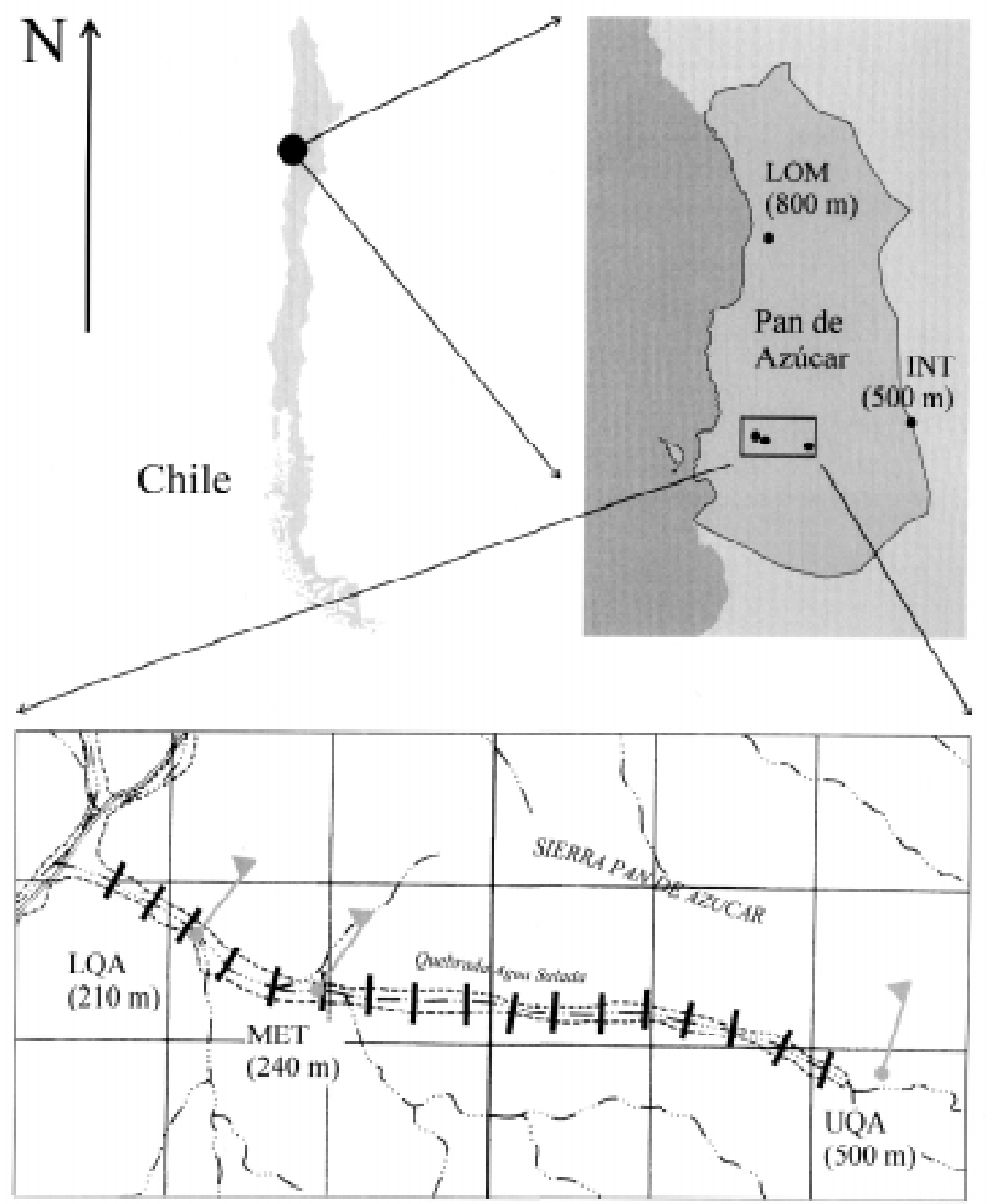

Fig. 1: Location of Parque Nacional Pan de Azúcar within Chile, with an accompanying map of the location of Quebrada Agua Salada and the five meteorological stations within the park, and with an insert of the placement of the transects and stations (LQA, MET, and UQA, next to flags) found within Quebrada Agua Salada. The grid spacing in the map of Quebrada Agua Salada is $1 \mathrm{~km}$. Also marked are the positions of the 17 vegetation transects (bars). See Table 1 for station details.

Localización del Parque Nacional Pan de Azúcar en Chile, con un mapa del sitio de la Quebrada Agua Salada y las cinco estaciones meteorológicas dentro del parque, y la ubicación de las estaciones (LQA, MET, y UQA, al lado de las banderas) encontradas en la Quebrada Agua Salada. El espaciamiento de la cuadrícula en el mapa de Quebrada Agua Salada es de 1 km. Los 17 transectos están marcados con barrillas. Ver Tabla 1 para más detalles de las citas. 
ture from the camanchaca. Rain is not an annual occurrence, and while all parts of the park will receive some rain, local topography concentrates rain water in some places more than others. The park may go without rain for as long as a decade at a time (see especially 1943 to 1985 in Fig. 2).

\section{Meteorological stations}

Five meteorological stations are currently in operation in the park (Fig. 1), one of which (LQA) since June, 1999 (Table 1). Three stations, LQA, MET, and UQA, were established in the middle of a $100 \mathrm{~m}$ wide arroyo (Quebrada Agua Salada), at 210,240 , and $500 \mathrm{~m}$, respectively. Two other stations, outside the arroyo, were established at the crown of a coastal escarpment in the park's high elevation fog-zone (LOM, $800 \mathrm{~m}$ ), and in the high elevation desert interior near the eastern limit of vegetation in the park (INT, $500 \mathrm{~m}$ ). These stations represent qualitatively different climates from those present in Quebrada Agua Salada. LOM is stationed at a site that, for most of the year, places it squarely within the camanchaca (fog). INT is stationed sufficiently distant from the ocean that it receives less rain than in the quebrada and seldom, if ever, experiences fog.

The primary meteorological station (MET) was outfitted with an anemometer (034A-L, MetOne Instruments, Grants Pass, Oregon, USA), and a temperature/relative humidity sensor (HMP45C, Vaisala Inc., Woburn, Massachusetts, USA). Data are registered every 30 seconds and averaged every 15 minutes using a relay multiplexer (AM416, Campbell Scientific Inc., Logan, Utah,

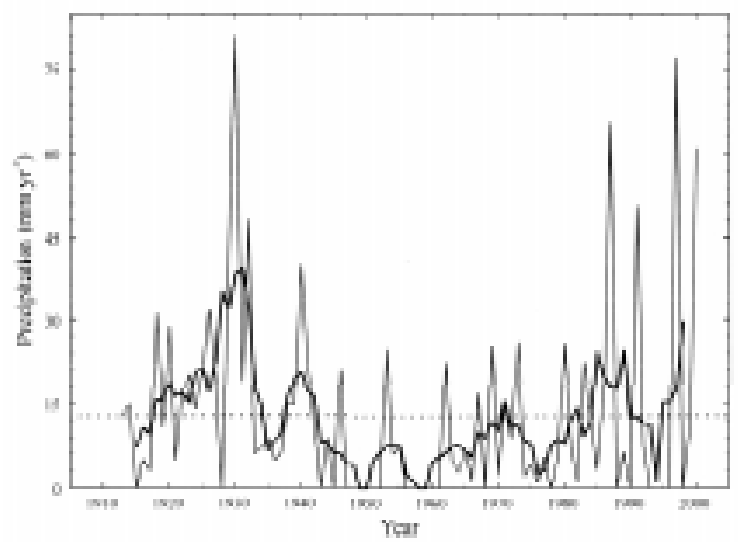

Fig. 2: Record of annual precipitation at Parque Nacional Pan de Azúcar for the period from 1913 to the present. The thin line is the annual rainfall rate, while the thicker line is a 5-year running mean of those data. The dotted line represents the mean precipitation rate for the period $(13.0 \mathrm{~mm}$ $\left.\mathrm{yr}^{-1}\right)$. The record represents a combination of records from a number of locations, including the town of Taltal to the north, Chañaral to the south, and later a pluviometer within the park itself. See text for details and sources.

Registro anual de precipitación en el Parque Nacional Pan de Azúcar entre 1913 y el presente. La línea angosta es la ocurrencia anual de lluvia, mientras que la línea más ancha es un promedio parcial de cinco años. La línea de puntos representa el promedio para este período (13,0 $\mathrm{mm}$ anual). El registro es una combinación de varias resúmenes de diferentes lugares, incluyendo la ciudad de Taltal al norte y Chañaral al sur, y luego un pluviómetro dentro del parque. El texto tiene las fuentes de los datos y mas detalles.

TABLE 1

Station descriptions. Data are presented through March 15, 2001

Descripción de estaciones. Los datos incluyen hasta el 15 de marzo de 2001

\begin{tabular}{|c|c|c|c|c|c|}
\hline $\begin{array}{l}\text { Station } \\
\text { acronym }\end{array}$ & Descriptions & Location & Elevation (m) & Instruments & Online date \\
\hline MET & $\begin{array}{l}\text { Main meteorological } \\
\text { tower }\end{array}$ & $26^{\circ} 09^{\prime \prime} \mathrm{S}, 70^{\circ} 37^{\prime \prime} \mathrm{W}$ & 240 & $\begin{array}{l}\text { Relative humidity } \\
\text { Temperature } \\
\text { Wind speed/direction }\end{array}$ & February $16,2000,19: 15$ \\
\hline LQA & $\begin{array}{l}\text { Lower Quebrada } \\
\text { Agua Salada }\end{array}$ & $26^{\circ} 09^{\prime} \mathrm{S}, 70^{\circ} 37^{\prime} \mathrm{W}$ & 210 & $\begin{array}{l}\text { Relative humidity } \\
\text { Temperature }\end{array}$ & June 20, 1999, 00:00 \\
\hline UQA & $\begin{array}{l}\text { Upper Quebrada } \\
\text { Agua Salada }\end{array}$ & $26^{\circ} 09^{\prime} \mathrm{S}, 70^{\circ} 35^{\prime} \mathrm{W}$ & 500 & $\begin{array}{l}\text { Relative humidity } \\
\text { Temperature }\end{array}$ & February $16,2000,00: 00$ \\
\hline INT & Park Interior & $26^{\circ} 08^{\prime} \mathrm{S}, 70^{\circ} 31^{\prime} \mathrm{W}$ & 500 & $\begin{array}{l}\text { Relative humidity } \\
\text { Temperature }\end{array}$ & February $16,2000,00: 00$ \\
\hline LOM & Lomitas & $26^{\circ} 00^{\prime} \mathrm{S}, 70^{\circ} 36^{\prime} \mathrm{W}$ & 800 & $\begin{array}{l}\text { Relative humidity } \\
\text { Temperature }\end{array}$ & February $16,2000,00: 00$ \\
\hline
\end{tabular}


USA) and datalogger (CR10X, Campbell Scientific Inc.) mounted on a $3 \mathrm{~m}$ tripod (CM10, Campbell Scientific Inc.) and powered by two 10 W solar panels (peak 0.57 A; MSX10, Campbell Scientific Inc.). The T/RH sensor and anemometer are secured to the tripod $3 \mathrm{~m}$ over open ground.

The other four, smaller stations are equipped with a small temperature/relative humidity sensor (part number H08-003-02 stationed at INT and H08-032-08 stationed at UQA, LQA and LOM, Onset Computer Corporation, Pocasset, Massachusetts, USA), set to register data once every 15 min. The sensors are protected from sunlight by a white, plate-style radiation shield (RS1, Onset Computer Corporation), and are set one meter above open ground.

The LQA station is also located in Quebrada Agua Salada, near the base of the arroyo at $210 \mathrm{~m}$ elevation, about $0.9 \mathrm{~km}$ to the west of the MET station. The UQA station is located at $500 \mathrm{~m}$ elevation at the upper extreme of the arroyo, at the base of a number of rocky bajadas. Fog arrives at UQA with some frequency, but the vegetation it supports is sufficiently similar to vegetation near LQA to ally it with the vegetation of that site.

The INT station is located in the open llanos plateaus in the park interior at $500 \mathrm{~m}$ elevation. The soil is gravelly, and the relief is shallower, meaning that runoff is less tightly concentrated than in the bajada communities. Moreover, field observations in May, 2000, following two small rain events, suggest that the site may dry faster following a rain than coastal sites due to lower cloud cover and, therefore, higher insolent radiation.

The LOM station is in the coastal fog zone at approximately $800 \mathrm{~m}$ elevation. The plant communities of this zone are typically large and diverse, supporting considerable avian and insect populations, and the soil is gravelly. Fog comprises a large proportion of this system's water supply, and plants appear healthy and exhibit new growth throughout the year and for many years following rain.

\section{Plant species}

There are diverse communities of perennial plants resident in the various lomas sectors in Pan de Azúcar. Three separate sectors were observed in this study, the first in Quebrada Agua Salada (near stations LQA, MET, and UQA), the second in the drier park interior (near station INT), and the third in Las Lomitas (near station LOM).

Within Quebrada Agua Salada, more than $97 \%$ of individuals in the surveyed section of the arroyo and of ground diameter greater than or equal to $0.5 \mathrm{~m}$ were comprised of the following species, in decreasing order of areal density (Table 2). Among these, the plant species Nolana mollis (Solanaceae) has been under study for the last two decades for its leaf salt excretion, believed to be an adaptation for water conservation (Mooney et al. 1980).

In the park interior, near the INT station, the vegetation is comprised of only a few common perennial species: Nolana divaricata (Solanaceae), N. leptophylla, N. flaccida, Tetragonia

\section{TABLE 2}

List of dominant perennial plant species in Quebrada Agua Salada, in order of decreasing areal density, from 130 to $470 \mathrm{~m}$ elevation. The percent of total areal density of the additional species, listed below, was less than $1 \%$

Lista de especies dominantes y perennes en Quebrada Agua Salada, en orden de densidad decreciente, desde

130 hasta $470 \mathrm{~m}$ de altitud. El porcentaje de la densidad total correspondiente a las especies adicionales fue menor a $1 \%$

\begin{tabular}{llc}
\hline Species & Family & $\begin{array}{r}\text { Percent of } \\
\text { total plant } \\
\text { cover by } \\
\text { areal density }\end{array}$ \\
& & 15.7 \\
Oxyphyllum ulicinum & Asteraceae & 14.4 \\
Polyachyrus cinereus & Asteraceae & 13.9 \\
Nolana mollis & Solanaceae & 13.8 \\
Tetragonia marítima & Aizoaceae & 8.6 \\
Ophryosporus sp. (prob. O. johnstonii) & Asteraceae & 6.4 \\
Gypothamnium pinifolium & Asteraceae & 5.5 \\
Eulychnia saint-pieana & Cactaceae & 4.0 \\
Nolana incana & Solanaceae & 3.1 \\
Heliotropium pycnophyllum & Boraginaceae & 2.7 \\
Ophryosporus triangularis & Asteraceae & 2.6 \\
Heliotropium linearifolium & Boraginaceae & 2.6 \\
Eremocharis fruticosa & Apiaceae & 2.6 \\
Atriplex deserticola & Chenopodiaceae & 2.2 \\
Loasa chilensis & Loasaceae & 2.0 \\
& &
\end{tabular}

Additional perennial species (in alphabetical order)

Copiapoa cinerea Euphorbia lactiflua Frankenia chilensis Nolana divaricata Nolana glauca Nolana sedifolia Polyachyrus fuscus
Cactaceae Euphorbiaceae Frankeniaceae Solanaceae Solanaceae Solanaceae Asteraceae 
maritima (Aizoaceae), Loasa chilensis (Loasaceae), and Heliotropium linearifolium (Boraginaceae). These species (except $N$. flaccida) are present in Quebrada Agua Salada. Overall areal plant density is considerably lower, however. Nolana flaccida, like $N$. mollis above, excretes leaf salt, apparently an adaptation for water conservation. Of all the Nolana species surveyed in the park (and there are as many as 18 perennial and annual Nolana species), only $N$. flaccida and $N$. mollis have been observed with highly active leaf salt glands, although there are reports that $N$. aplocaryoides (an annual) also has foliar salt excretion (Johnston 1929).

In Las Lomitas, near the LOM station, the cacti are conspicuously represented by Eulychnia saintpieana (Cactaceae), the spines of which support numerous fruticose lichens and occasionally the large epiphyte Tillandsia geissei (Bromeliaceae). Other common species include Polypodium espinosae (Polypodiaceae), Euphorbia lactiflua (Euphorbiaceae), Oxalis gigantea (Oxalidaceae), Heliotropium linearifolium, Puya boliviensis (Bromeliaceae), and Tetragonia maritima. A number of species, quite common in Quebrada Agua Salada, are completely absent in Las Lomitas, including Oxyphyllum ulicinum (Asteraceae), Polyachyrus cinereus (Asteraceae), Nolana mollis, and Gypothamnium pinifolium (Asteraceae). No salt-excreting species of Nolana are present in this high-elevation, fog-dominated community.

\section{Plant survey}

A survey of plant distribution in Quebrada Agua Salada was performed in January, 2001, measuring plant number and areal density as a function of distance and elevation along the arroyo. From an elevation of $128 \mathrm{~m}$ in the initial stretches of the arroyo to an elevation $471 \mathrm{~m}$ near the source, seventeen 0.3 ha transects, each spanning the entire width of the arroyo, were established at 300 $\mathrm{m}$ intervals over a distance of $4.85 \mathrm{~km}$ (Fig. 1). Plants were marked using a GPS transceiver (GPS 12, Garmin International Inc., Olathe, Kansas, USA) and counted along with measurements of their major and minor canopy diameters. All plants of diameter greater than $0.5 \mathrm{~m}$ were counted, as were all individuals of Eulychnia saint-pieana regardless of size and all individuals of Ophryosporus sp. (Asteraceae) of diameter greater than $0.15 \mathrm{~m}$, for a total of 2098 plants in all. Transect area was measured using a GPS tranceiver.

\section{Data analysis}

Relative humidity and temperature data were collected from each station, and anemometric data from the MET station, through March 16, 2000. Mean, minimum, and maximum daily air temperatures $\left({ }^{\circ} \mathrm{C}\right)$ were calculated for each station, as well as mean daily dewpoint $\left({ }^{\circ} \mathrm{C}\right)$. Failure of the humidity sensor at the LQA station in mid-October precluded calculation of the dewpoint at that station after that time. Dewpoint and vapor pressure deficit were determined by first calculating the saturated vapor pressure from air temperature using the following empirical formula (Richards 1971):

$$
\begin{aligned}
e_{s}= & 0.61092+0.0443935 T+1.42955 \times 10^{-3} T^{2}+2.64544 \times 10^{-5} T^{3} \\
& +3.02153 \times 10^{-7} T^{4}+2.06912 \times 10^{-9} T^{5}+6.6369 \times 10^{-12} T^{6} \\
& -9.36518 \times 10^{-15} T^{7}
\end{aligned}
$$

Where $e_{s}$ is in $\mathrm{kPa}$ and $T$ is in ${ }^{\circ} \mathrm{C}$. Actual vapor pressure, $e_{a}$, is then found by multiplying $e_{s}$ and relative humidity. The dewpoint is the temperature corresponding to the $e_{a}$ according to equation. The vapor pressure deficit, or VPD, is the difference between the saturated and actual vapor pressures (in $\mathrm{kPa}$ ). Temperature and dewpoint data exhibited substantial day-to-day variation. In some cases, a 5-day running-mean filter was used to smooth the data allowing better visualization of long-term trends.

Two methods were used to assess temperature variation with altitude. The first calculated the simple difference in temperature between each site and the lowest elevation site (LQA). This was done following the application of a 5-day running-mean filter. The second involved finding the least-squares rate of change in temperature with elevation (or adiabatic lapse rate) among the three stations in Quebrada Agua Salada. This calculation did not require the application of a filter.

Seasonal and diurnal variation in wind speed and direction were calculated from anemometric data collected at the MET station from March 1, 2000, to March 1, 2001. One annual and twelve monthly radial histograms of wind speed and direction were constructed. The monthly histograms were made comparable by constructing each such that the frequency scale was normalized by the entire year's advection data. The topography of the quebrada enforced a particular distribution of wind directions, wherein most of the advection was marine in origin, with some arising from the inland desert, especially in the winter and at night. The temperature and humidity characteristics of inland versus marine air was compared by calculating the specific humidity 
(unitless), potential temperature (K), and wind strength along the predominant $\mathrm{E}-\mathrm{W}$ wind track $\left(95^{\circ}-275^{\circ}\right)$. Specific humidity $q$, which provides an estimate of humidity unbiased by air temperature or pressure, is given by the following relation:

$$
q=\frac{0.622_{a}}{p-(1-0.622) e_{a}}
$$

where $p$ is air pressure, here assumed to be 1,015 mbar, and 0.622 is the ratio of dry to wet air gas constants. Potential temperature $\theta$, which, like specific humidity, provides an estimate of temperature unbiased by air pressure or humidity, is given by the following relation:

$$
\theta=T\left(\frac{1015}{p}\right)^{\frac{287}{C_{p}}}
$$

where 1,015 mbar is air pressure at sea level, $\mathrm{p}$ is the pressure at the station (here assumed to 1,015 mbar, thus reducing the quantity in parentheses to unity), 287 is the dry air gas constant, and $C_{p}$ is specific heat of air, which is given by the following relation:

$$
C_{p}=1004(1+0.85 q)
$$

where $q$ is specific humidity, as before. When normalized by the magnitude of the E-W wind vector, the mean specific humidity and potential temperatures can be calculated for marine and inland air packets as unbiased quantities describing the latent and sensible heat content of the air.

Data analysis was performed using MATLAB 6.0, Release 12 (The MathWorks Inc., Natick, Massachusetts, USA). The relevant MATLAB Mfile scripts are available upon request.

\section{RESULTS}

\section{Precipitation}

The occurrence of rainfall is associated with a collapse in the marine inversion layer and convection of moist, warm air near the ocean surface. Some significant rainfall events are closely associated, therefore, with warm-water ENSO events, as prevailing easterly winds subside and the rate of deep-ocean upwelling is reduced. Notable years are 1930, 1932, 1940, 1987, 1991, and 1997, each associated with annual precipitation in excess of $40 \mathrm{~mm}$ either within the park or in nearby towns. It is by no means a foregone conclusion, however, that every warm event will bring precipitation. As pointed out by Dillon \& Hoffmann (1997), ENSO warm events may only enhance fog and bring no precipitation at all. Moreover, some significant precipitation events are known to occur outside of warm ENSO events, such as during 2000 when sea surface temperatures were relatively low. Rainfall typically occurs in the late fall, winter, and early spring months (May through October).

The absence of a network of rainfall stations within Pan de Azúcar makes it impossible to determine the geographic distribution of rainfall within the park. Only a broad overview of rainfall events over the last century prior to 1996 from stations either within or near the park can be attained, and even then these data can be interpreted only as a potential record of how much precipitation may have fallen at the study area. Recently, a pluviometer was installed at a park site near the coast, which, with its greater proximity, gives estimates of local precipitation superior to those of the nearby towns of Taltal and Chañaral. Some evidence, however, is available that rainfall events are intercepted by large portions of the park at the same time and at approximately the same rate. On May 14 and 15, 2000, the park pluviometer registered $7.5 \mathrm{~mm}$ of rain, which was reflected in approximately the same degree of soil water penetration at each meteorological station $(15 \mathrm{~cm}$, personal observation, MVT). However, drying following that rainfall event depended strongly on location. The relatively cloudless sky over the INT station afforded considerably faster drying rates than in any of the sites in Quebrada Agua Salada or at Las Lomitas. Moreover, while rainfall interception may be spatially homogeneous, local relief has a profound effect in concentrating moisture in arroyos, bajadas, and azonal coastal communities.

\section{Air temperature and moisture}

More than a year of temperature, relative humidity, and anemometric data are now available for five locations in Pan de Azúcar. The LQA sensor, installed in June, 1999, suffered a malfunction in its humidity sensor at some point during the month of October, 2000, yet a complete record of temperature is available from that station for the 20 month period from June, 1999, to March, 2001. Mean daily temperature is shown in Fig. 3. The range of mean temperatures for the entire period does not exceed $10{ }^{\circ} \mathrm{C}$, with the dewpoint approximately $5{ }^{\circ} \mathrm{C}$ cooler than air temperature throughout the measurement period (until October, 2000). VPD was highest during the summer (at 0.8 to $1.0 \mathrm{kPa}$, Fig. 3), though not particularly 


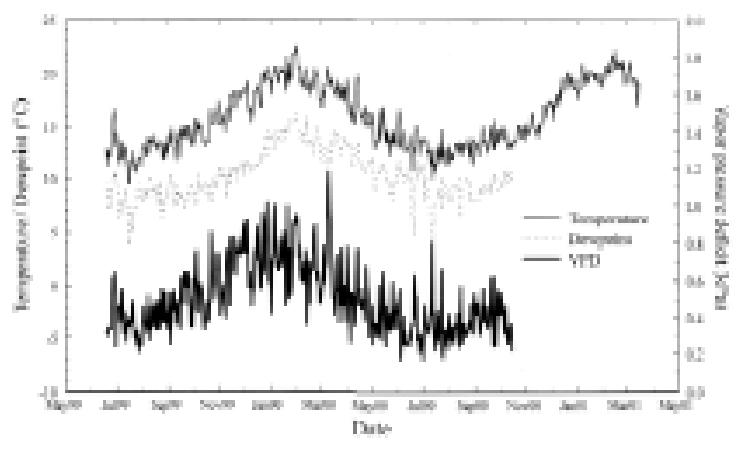

Fig. 3: Mean daily air temperature, dewpoint and vapor pressure deficit at the LQA station from mid-June, 1999, to mid-March, 2001. Maximum, minimum and mean temperatures and dewpoints for each month of the record are given for this station in Table 3. Dewpoint and VPD data are missing after mid-October, 2000, due to sensor failure.

Promedio diario de la temperatura, punto de rocío, y déficit de presión de vapor del aire cerca de la estación LQA entre mediados de junio de 1999 y mediados de marzo de 2001.

Los máximos, mínimos y promedios de la temperatura, y el punto de rocío,m están listados en Tabla 2. El punto de rocío y el déficit de presión de vapor (VPD) no están disponibles después la mitad de octubre de 2000, debido a una falla del sensor.

high for desert ecosystems, where mean VPDs may often exceed 2.5 or $3.0 \mathrm{kPa}$. Peak temperatures are observed in the months of January and February in both years for which data are available (Table 3).

Minimum and maximum daily temperatures for all stations (following the application of a fiveday running-mean filter) are given in Fig. 4. Minimum annual temperatures are attendant in the months of July and August, reaching as low as 2.9 ${ }^{\circ} \mathrm{C}$ at the LOM station in July, 2000. Yet, despite the potential for very low temperatures, the winter months at this high elevation site are by no means cold. While the annual minimum temperature was recorded in July, 2000, the annual maximum temperature at the LOM station $\left(26.1^{\circ} \mathrm{C}\right)$ was recorded the previous month in June, only to be followed by a $25.5^{\circ} \mathrm{C}$ day in August. These temperatures are not only high for this site, but high for the entire park at any time of the year. The highest recorded temperature in the park during the same measurement period was $26.6^{\circ} \mathrm{C}$ in February, 2001. Moreover, the highest VPD at the LOM station was observed in the winter with values as high as $3.0 \mathrm{kPa}$, while the highest at the LQA station was recorded in the summer months in the range of $2.0 \mathrm{kPa}$. Even at the INT site, a relatively dry site compared to those located in
Quebrada Agua Salada, VPDs did not exceed 2.5 $\mathrm{kPa}$ (though the highest values were observed during the winter months, as at the LOM station). The cause of this high winter temperature variability and the high winter VPDs at the LOM station will be discussed below. It appears to be that the higher the elevation, the higher the probability of experiencing hot, dry periods during the winter. In contrast, during the summer, temperature follows the stereotypical pattern of decreasing with increases in elevation (Fig. 5).

During the spring and summer months, the adiabatic lapse rate in Quebrada Agua Salada (Fig. 6) is a relatively stable $-6.3{ }^{\circ} \mathrm{C} / 1,000 \mathrm{~m}$, near the global mean value of $-6.5^{\circ} \mathrm{C} / 1,000 \mathrm{~m}$ (Hartmann 1994). During the winter, the lapse rate becomes considerably more erratic, and even positive, with mean temperatures at high elevations sometimes far exceeding temperatures at low elevations, especially in June, July, and August.

Throughout the year, a progressive drop in dewpoint is present as one goes from the LQA station at the base of Quebrada Agua Salada, through to the UQA station at its source, and then to the INT and LOM stations (Fig. 7). Moreover, the dewpoint drops precipitously at the high elevations stations during the winter months, especially at LOM, a drop correlated with significantly higher maximum temperatures despite the overall cooling in minimum temperatures.

\section{Advection}

Wind vectors measured at the MET station in Quebrada Agua Salada are bimodally distributed (Fig. 8), with the majority of the wind arriving from the west (marine air) from a mean heading of $286^{\circ}$ (trade winds) and a small quantity from the east (inland air) from a heading of $85^{\circ}$. This distribution follows the local relief of Quebrada Agua Salada, which channels most of the air in an E-W direction (Fig. 1). The predominance of marine advection in the arroyo is a function of the strong influence sea surface heating has on the coastal air mass along eastern South America. A strong onshore breeze should be highly correlated with high humidity, a stable adiabatic lapse rate, and a vertical inversion layer.

Although, the majority of advection is marine, during the winter months wind speeds decline and an increasing amount of wind arrives from the inland desert (Fig. 9). In fact, in May, June, and July almost an equal amount of advection arrives from the inland desert as from the ocean (Fig. 10). Throughout the year, inland air is both drier (by 5 $\%$, on average) and cooler (by $2.5 \mathrm{~K}$ ) than marine 
air. The inland air is cooler predominantly because most of inland advection, if it comes at all, comes at night (Fig. 11). Moreover, high specific humidities can be expected in the summer when higher insolent radiation increases the rate of sea surface evaporation.
Most importantly, throughout the entire late spring and early summer, between November and March, marine advection nearly completely dominates the inland, offshore breeze. Because the stability of the temperature inversion depends on a consistent high-humidity, onshore breeze
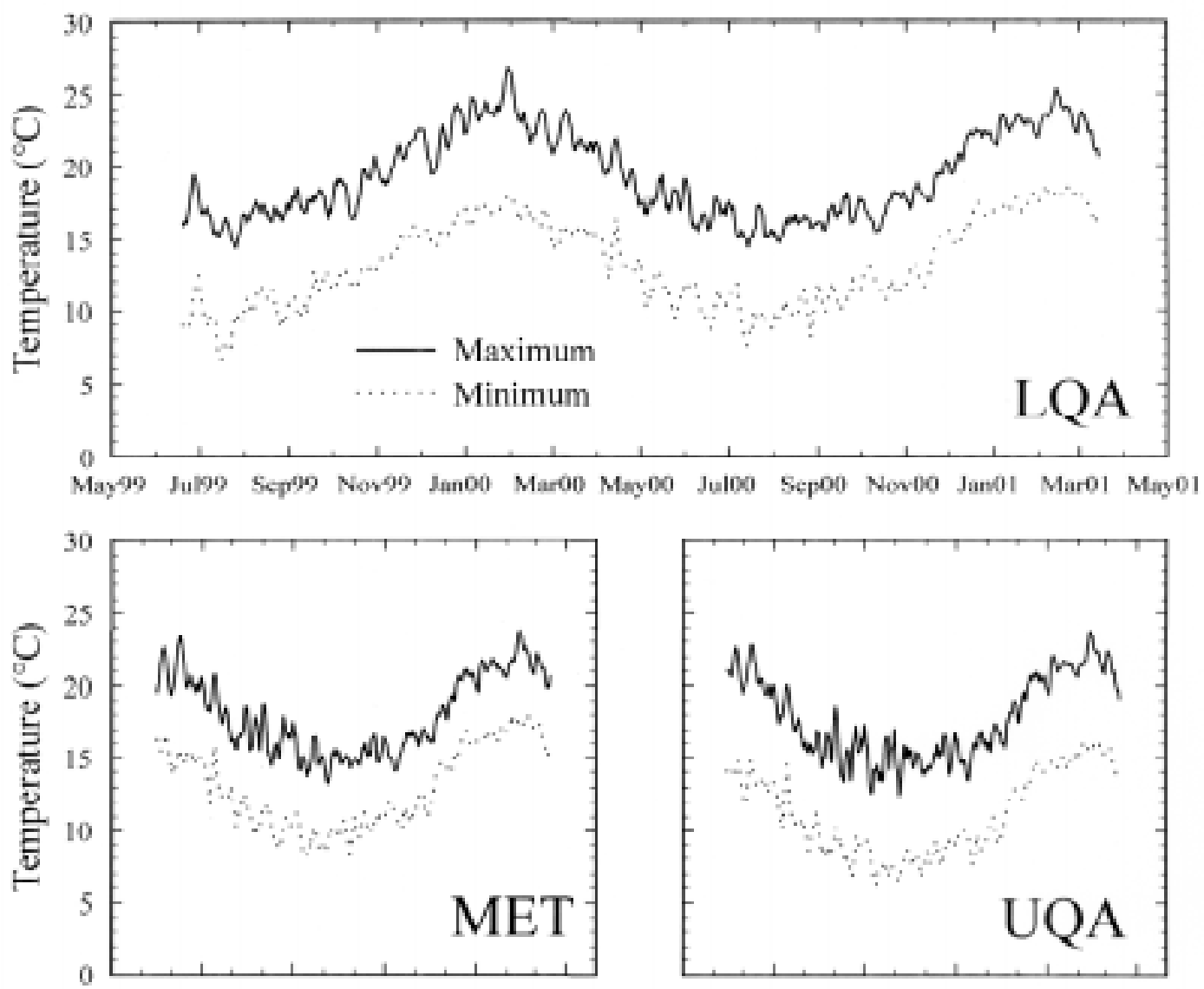

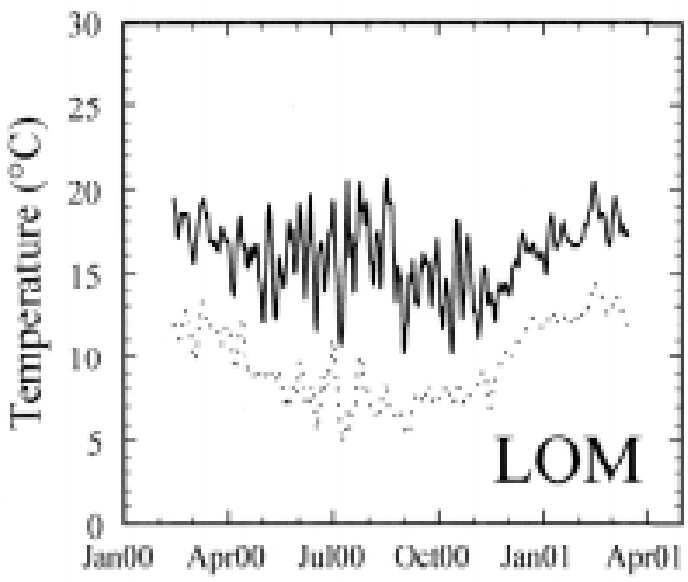

Date

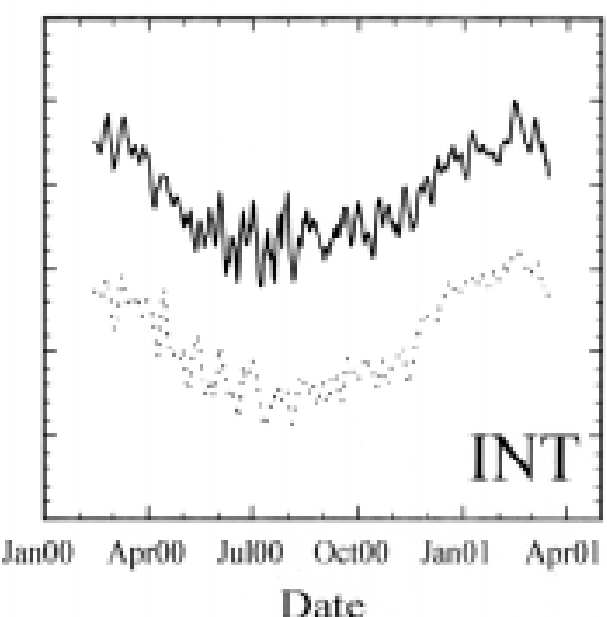

Date

Fig. 4: The five-day running mean of the minimum and maximum air temperatures at each station. Promedio parcial de cinco días de los mínimos y máximos de la temperatura del aire cerca de cada estación. 
(Trewartha 1981), we can expect the inversion to be highly stable during the late spring, summer and early fall months.

Diurnal variations in wind speed and direction, and moisture content and temperature (Fig. 11), show that during the summer there is almost no offshore breeze and that the humidity of the air mass over that site is nearly constant. During the winter, on the other hand, when the land-sea breeze cycle is enhanced, there is considerable diurnal variation in specific humidity, correlated with the night-time breeze from the inland desert. As night falls, wind begins to pick up from the east, lowering atmospheric humidity. At day break, winds shift to the west and the humidity rises as marine air moves east (Fig. 11).

TABLE 3

Summary of monthly mean, maximum and minimum air temperature and dewpoint at the stations used in this study. Statistics are calculated only when data are available for the entire month. Data are presented in the format "mean (minimum, maximum)". All data are in ${ }^{\circ} \mathrm{C}$.

LQA dewpoint data is unavailable after September, 2000, due to sensor malfunction

Resumen de los valores promedios, máximos y mínimos de la temperatura y el punto del rocío del aire cerca de las estaciones utilizadas en este estudio. Las estadísticas se calcularon solo si se dispuso de datos para el mes completo. Los datos se presentan en el de acuerdo al siguiente formato: "promedio (mínimo, máximo)". Todos los datos están en unidades de ${ }^{\circ} \mathrm{C}$. El punto de rocío de la estación LQA no está disponible después de septiembre de 2000 por falla en el sensor

\begin{tabular}{|c|c|c|c|c|c|c|c|}
\hline \multirow[t]{2}{*}{ Year } & \multirow[t]{2}{*}{ Month } & \multicolumn{2}{|c|}{ LQA } & \multicolumn{2}{|c|}{ MET } & \multicolumn{2}{|c|}{ UQA } \\
\hline & & Temperature & Dewpoint & Temperature & Dewpoint & Temperature & Dewpoint \\
\hline \multirow[t]{6}{*}{1999} & 7 & $11.9(5.4,17.8)$ & $7.5(-3.2,11.0)$ & - & - & - & - \\
\hline & 8 & $13.2(7.4,18.3)$ & $8.5(-0.1,11.9)$ & - & - & - & - \\
\hline & 9 & $13.9(8.2,19.9)$ & $8.7(4.5,11.6)$ & - & - & - & - \\
\hline & 10 & $15.0(9.7,21.7)$ & $9.1(5.7,12.2)$ & - & - & - & - \\
\hline & 11 & $16.9(12.2,22.8)$ & $10.4(7.8,12.7)$ & - & - & - & - \\
\hline & 12 & $18.2(12.9,25.5)$ & $11.9(8.9,15.2)$ & - & - & - & - \\
\hline \multirow[t]{12}{*}{2000} & 1 & $20.1(14.5,27.5)$ & $14.5(10.5,17.5)$ & - & - & - & - \\
\hline & 2 & $19.5(14.0,26.7)$ & $14.2(11.3,16.8)$ & - & - & - & - \\
\hline & 3 & $18.4(12.6,24.8)$ & $13.0(7.3,15.6)$ & $17.7(12.5,25.0)$ & $12.8(7.5,15.3)$ & $16.4(10.8,23.9)$ & $12.2(7.5,14.7)$ \\
\hline & 4 & $16.7(11.1,23.6)$ & $12.0(8.7,16.4)$ & $15.9(10.7,22.7)$ & $11.7(8.5,15.9)$ & $14.3(8.9,22.1)$ & $11.3(8.0,14.9)$ \\
\hline & 5 & $14.3(8.6,21.3)$ & $10.1(-2.1,13.7)$ & $13.7(8.5,21.0)$ & $9.8(-3.9,13.3)$ & $12.1(6.9,20.3)$ & $9.3(-9.4,12.9)$ \\
\hline & 6 & $13.5(8.0,21.7)$ & $9.8(-5.5,14.2)$ & $13.1(7.9,21.2)$ & $9.3(-6.7,13.7)$ & $11.6(5.1,21.7)$ & $8.6(-7.9,13.3)$ \\
\hline & 7 & $12.5(6.1,22.2)$ & $8.3(-11.0,12.5)$ & $12.0(6.8,22.8)$ & $7.8(-12.9,12.1)$ & $10.7(4.4,23.8)$ & $6.6(-15.3,11.9)$ \\
\hline & 8 & $12.9(6.8,17.8)$ & $8.9(-5.7,11.7)$ & $12.1(5.9,17.3)$ & $8.6(-6.6,11.7)$ & $10.6(5.6,20.2)$ & $8.0(-8.7,11.5)$ \\
\hline & 9 & $13.6(8.6,19.6)$ & $9.1(2.9,11.7)$ & $12.8(8.4,18.8)$ & $9.1(4.6,11.7)$ & $11.4(6.0,18.5)$ & $8.8(3.6,11.4)$ \\
\hline & 10 & $14.1(9.5,18.8)$ & - & $13.2(8.9,19.0)$ & $9.8(5.2,11.5)$ & $11.8(6.4,19.0)$ & $9.6(4.1,11.8)$ \\
\hline & 11 & $15.6(10.5,20.8)$ & - & $14.7(10.4,19.0)$ & $10.9(7.0,13.6)$ & $13.5(8.6,19.9)$ & $10.7(7.1,13.3)$ \\
\hline & 12 & $18.4(13.4,23.9)$ & - & $17.4(12.8,22.4)$ & $13.0(9.8,15.9)$ & $16.2(11.3,22.2)$ & $12.9(10.3,15.1)$ \\
\hline \multirow[t]{2}{*}{2001} & 1 & $19.5(15.2,25.1)$ & - & $18.5(14.4,23.4)$ & $13.9(11.1,16.4)$ & $17.3(13.2,23.3)$ & $13.7(11.4,16.1)$ \\
\hline & 2 & $20.5(16.1,26.6)$ & - & $19.5(15.7,25.0)$ & $14.8(12.3,16.6)$ & $18.3(14.1,24.8)$ & $14.7(12.1,16.7)$ \\
\hline
\end{tabular}

\begin{tabular}{lllllll}
\multicolumn{3}{c}{} & \multicolumn{2}{c}{ LOM } & & \multicolumn{2}{c}{ INT } \\
\cline { 3 - 4 } \cline { 5 - 6 } Year & Month & Temperature & Dewpoint & & Temperature & Dewpoint \\
\hline \multirow{2}{*}{2000} & 3 & $13.9(8.1,21.4)$ & $11.8(3.6,14.8)$ & & $16.7(10.2,25.6)$ & $12.0(6.2,15.8)$ \\
& 4 & $12.3(8.1,20.5)$ & $10.6(-2.9,14.2)$ & & $14.5(8.6,22.5)$ & $10.7(7.3,15.4)$ \\
& 5 & $11.2(5.9,23.2)$ & $7.6(-15.0,12.1)$ & & $12.2(5.8,21.3)$ & $8.4(-7.2,12.3)$ \\
& 6 & $11.2(4.0,26.1)$ & $6.7(-16.5,13.2)$ & & $11.8(4.2,24.0)$ & $7.8(-7.1,12.5)$ \\
& 7 & $11.4(2.9,23.8)$ & $1.9(-24.1,12.3)$ & & $11.3(3.7,25.6)$ & $5.8(-10.3,11.2)$ \\
& 8 & $10.6(5.4,25.5)$ & $4.7(-18.8,12.4)$ & & $11.1(5.0,23.2)$ & $7.1(-9.1,10.6)$ \\
& 9 & $9.8(4.7,19.8)$ & $7.1(-19.2,11.6)$ & & $11.7(5.4,20.6)$ & $7.8(-0.2,11.0)$ \\
& 10 & $10.2(6.2,23.2)$ & $7.6(-21.0,12.8)$ & & $12.3(6.6,22.5)$ & $8.7(3.2,10.7)$ \\
& 11 & $10.7(5.6,19.1)$ & $9.6(-6.3,12.9)$ & & $13.9(7.4,21.3)$ & $9.6(4.9,12.0)$ \\
& 12 & $13.0(8.7,18.8)$ & $12.4(-0.1,15.1)$ & & $16.5(10.6,24.4)$ & $11.8(8.8,14.2)$ \\
& 1 & $14.0(11.1,20.3)$ & $13.3(6.4,16.5)$ & & $17.5(12.2,24.4)$ & $12.6(10.1,15.4)$ \\
& 2 & $15.2(11.4,21.4)$ & $14.3(11.1,17.0)$ & & $18.6(13.3,26.0)$ & $13.5(10.9,15.8)$ \\
\hline
\end{tabular}




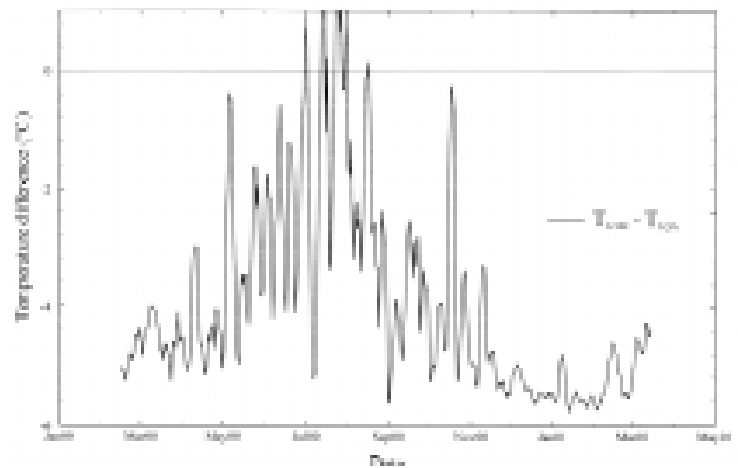

Fig. 5: Difference in air temperature between the lowest elevation site (LQA) and the high-elevation fog-zone site (LOM) from mid-February, 2000 (mid-summer), to mid-March, 2001 (late summer). The difference was calculated following application of a five-day running-mean filter.

Diferencia en la temperatura del aire entre el sitio de elevación más baja (LQA) y el sitio de mayor altitud en la zona de niebla (LOM) desde la mitad de febrero de 2000 (medio verano), y hasta mediados de marzo de 2001 (verano tardío). La diferencia fue calculada después de la aplicación de un filtro de promedio parcial de cinco días.

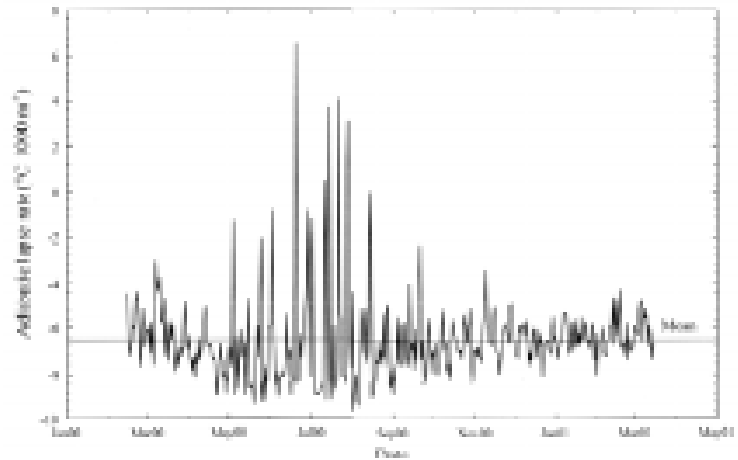

Fig. 6: Observed lapse rate $\left({ }^{\circ} \mathrm{C} 1,000 \mathrm{~m}^{-1}\right)$ along Quebrada Agua Salada derived as the slope of the least-squares line fitted to unfiltered, mean daily temperatures from the LQA (210 m elevation), MET (240 m), and UQA (500 m) stations.

El "lapse rate" de temperatura $\left({ }^{\circ} \mathrm{C} 1.000 \mathrm{~m}^{-1}\right)$ a lo largo de la Quebrada Agua Salada derivada como la pendiente de la línea "least-squares" ajustada a los promedios diarios y no filtrados de temperatura del aire de los sitios LQA (210 m de altitud), MET (240 m), y UQA (500 m)

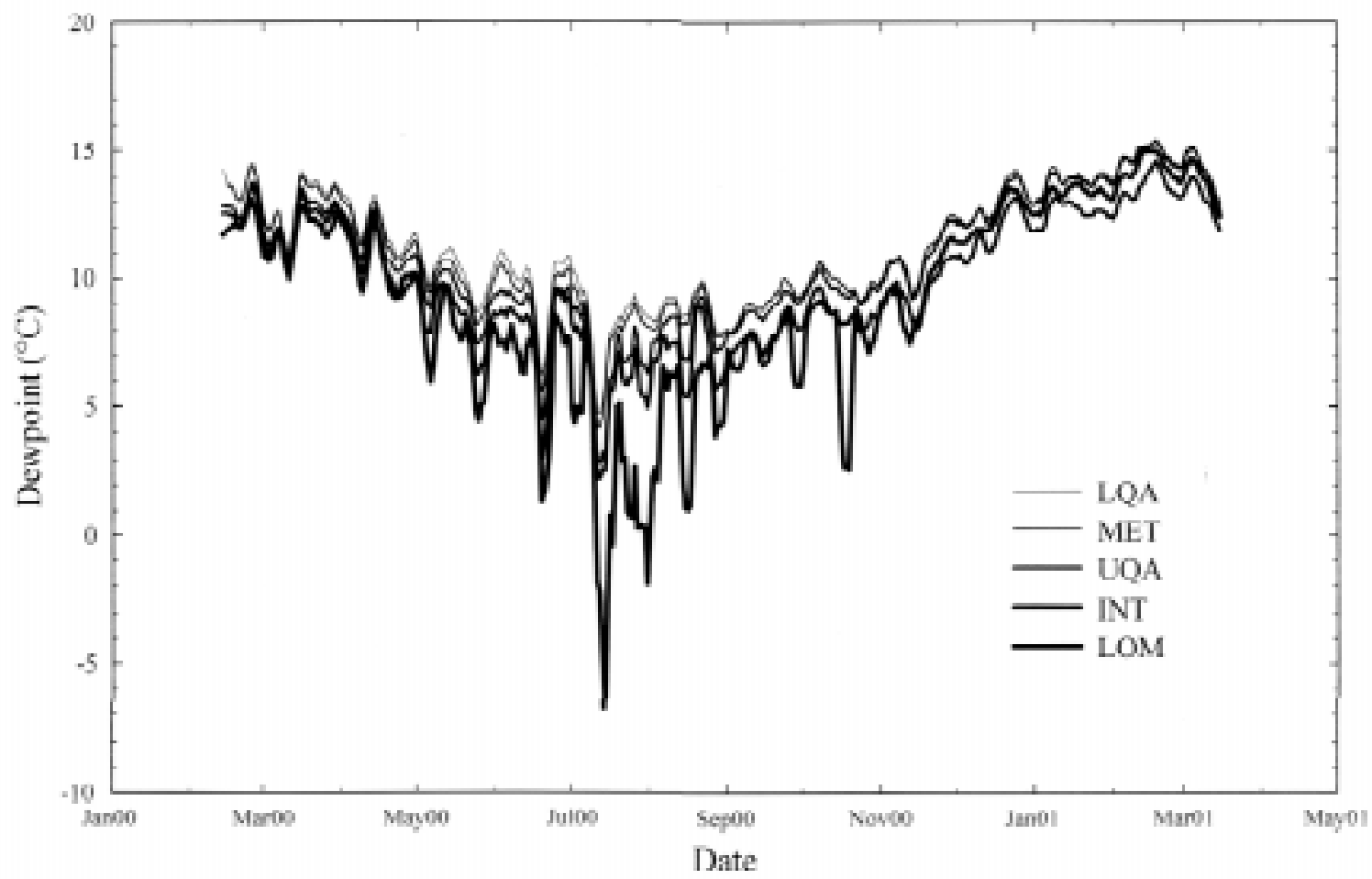

Fig. 7: Dewpoint at each site from mid-February, 2000 (mid-summer), to mid-March, 2000 (late summer), shown following application of a five-day running-mean filter.

El promedio parcial de cinco días del punto de rocío de cada sitio desde la mitad de febrero de 2000 (a mitad del verano), y hasta mediados de marzo de 2000 (verano tardío). 


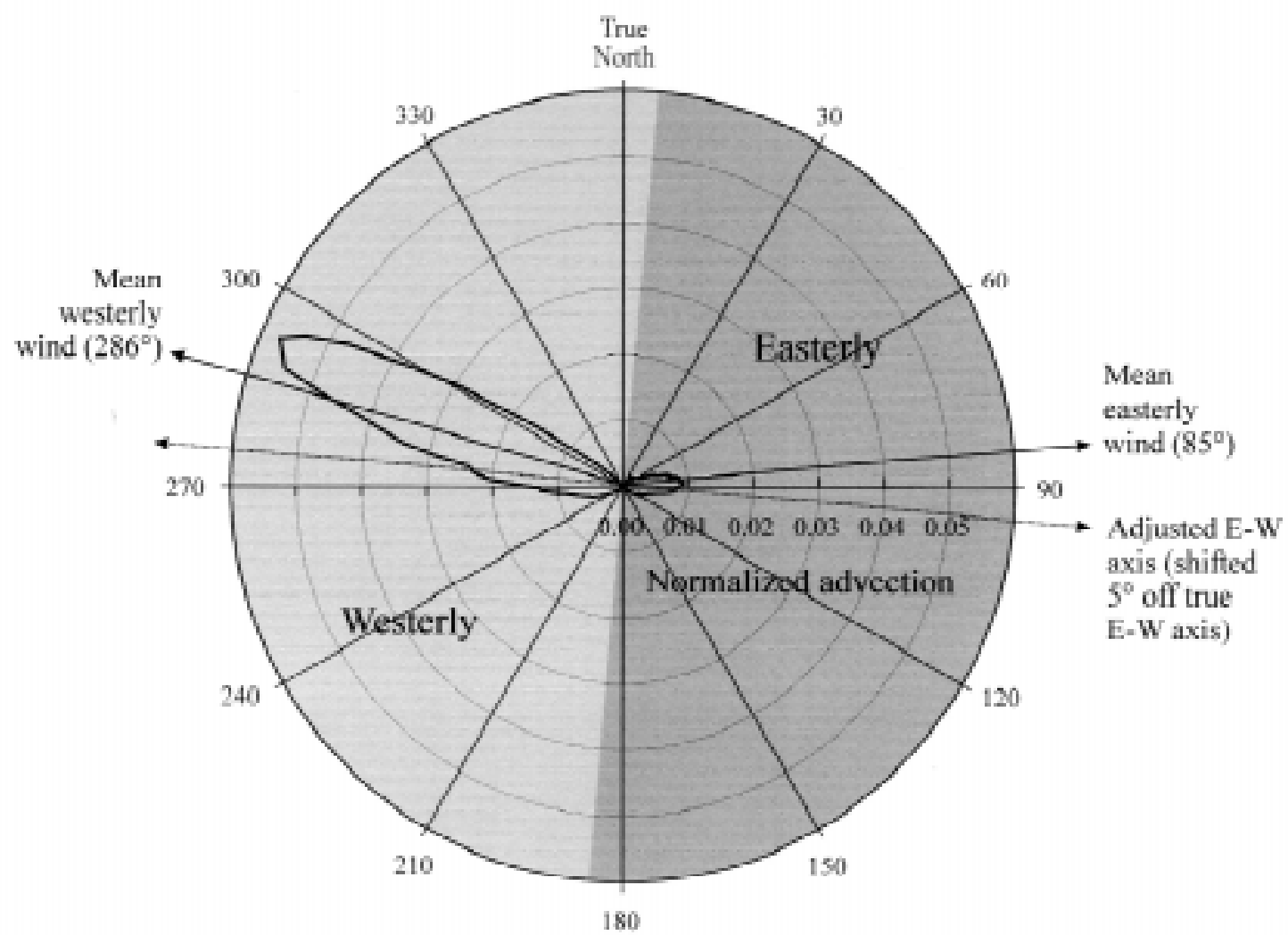

Fig. 8: Polar histogram of normalized advection in each of 180 two-degree bins from March 1, 2000, to February 28, 2001, at the MET station. Total advection over this period is calculated as the sum over time of the product of each measured wind velocity and the time over which each was measured, and is thus in units of distance $(\mathrm{km})$. These values are then normalized by dividing each by the total advection measured over all bins. The vast majority of the measured advection is from the west and is marine air (mean $\left.286^{\circ}\right)$. Some advection is from the east $\left(85^{\circ}\right)$ representing air from the inland desert. The mean of these two wind directions is on the $5^{\circ}-185^{\circ}$ axis. Therefore, we define any wind east of this axis as an easterly wind, and any wind west of that axis as a westerly wind.

Histograma polar de la advección normalizada en cada una de 180 casillas de dos grados, desde el 1 de marzo de 2000 , hasta el 28 de febrero de 2001 cerca de la estación MET. La advección total en este período se calculó como la suma sobre tiempo de la velocidad del viento por el tiempo con que se registró, y por lo tanto tiene unidades de distancia (km). Dichos valores han sido divididos por el total de advección de todas las casillas para representar la proporción de advección del total para cada casilla. La gran mayoría de advección registrada venía del oeste y es aire marítimo (promedio $286^{\circ}$ ). Una parte de la advección vino desde el este $\left(85^{\circ}\right)$ y que representa el aire que viene desde el interior del desierto. El promedio de estas direcciones es el eje $5^{\circ}-185^{\circ}$. Entonces, cualquier viento que viene del este de ese eje es un viento del este, y el opuesto es un viento del oeste.

Some relation can be seen between the number and degree of high-temperature, low-humidity excursions at the LOM site and the quantity of westerly advection measured at the MET site (Fig. 12). As westerly winds increase and dominate during the spring, summer, and early fall months, maximum daily VPD at the LOM site stays below $1.5 \mathrm{kPa}$. During the winter, however, westerly winds drop in intensity, and the maximum daily VPD can rise to over $3 \mathrm{kPa}$, as observed on two days in June and August, 2000. There is a delay of almost a month and a half between the time of minimum westerly advection (mid-June, 2000) and the time of maximum VPD (late-July, 2000). Thus, a drop in advection may cause an increase in maximum daily VPD, but there must be other factors involved, most likely the increase in subsidence and heating aloft in the cool winter months (Trewartha 1981).

\section{Plant distribution}

The distribution of eight dominant perennial plant species is shown in Fig. 13. The most notable 

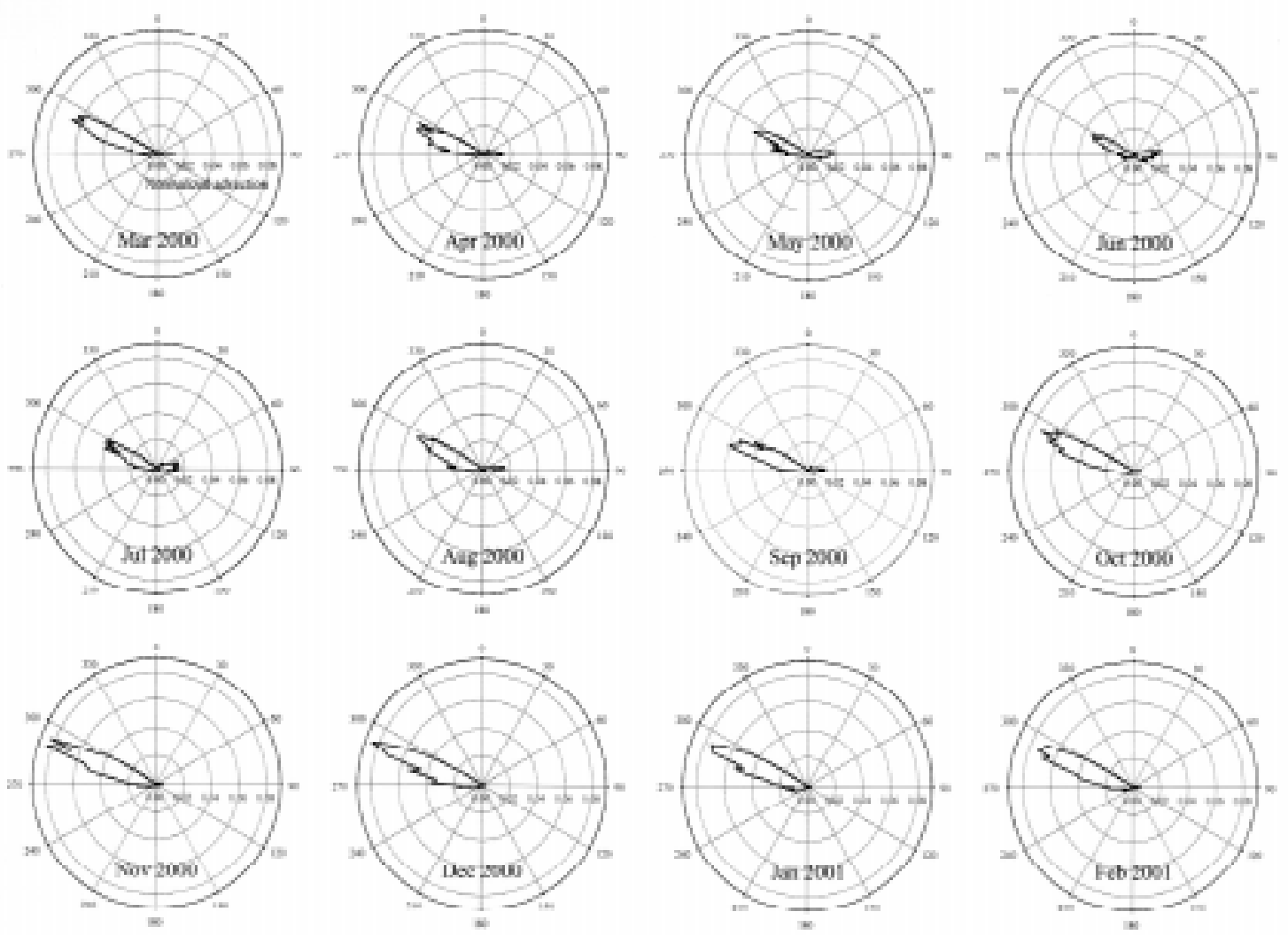

Fig. 9: Monthly polar histograms of advection at the MET station. The data are the same as in Fig. 8, but broken down by month from March, 2000, to February, 2001.

Histogramas mensuales de advección en la estación MET. Los datos son de la misma fuente como los de la Fig. 8, pero separados por mes entre marzo de 2000 y febrero de 2001.

trends are a sharp and distinct increase in the density of Oxyphyllum ulicinum with elevation from zero representatives below $130 \mathrm{~m}$, to high density above $350 \mathrm{~m}$. Conversely, there is a dramatic decrease in the density of Gypothamnium pinifolium from extremely high density at $130 \mathrm{~m}$ to zero at $370 \mathrm{~m}$ elevation-although it does returns above the fog zone in nearby parts of the Atacama. A general increase can also be observed for Nolana incana and Eulychnia saintpieana, as well as a sharp decrease above $260 \mathrm{~m}$ for Polyachyrus cinereus. While all of these species have representatives throughout nearly the entire arroyo, some of these trends are sufficiently intense to warrant further speculation. At the higher elevation transects, plants are exposed to generally cooler temperatures, with hightemperature, low-humidity excursions during the winter (see above). Low-elevation sites, though far from any fog development, possess a more stable climate, with high atmospheric humidity and low temperature throughout the year.
Near the INT station, plant density is relatively low, and dominated by only a few species, notably, as mentioned above, Nolana flaccida, Loasa chilensis, Tetragonia maritima, and Heliotropium linearifolium. The interior portions of the park are the only parts in which one finds $N$. flaccida, which may be a function of lower competition and its capacity for excreting salt on its leaves to trap atmospheric moisture. All plants in the area are scrambling bushes with large quantities of older, dead branches in minimal states of decomposition either on the ground or still attached to the main stem.

Near the LOM station, plant density is considerably higher, but with no representation from many of those species particularly common to Quebrada Agua Salada, including Oxyphyllum ulicinum, Polyachyrus cinereus, Nolana mollis, and Gypothamnium pinifolium. As mentioned earlier, no salt-excreting species of Nolana, such as $N$. mollis and N. flaccida, is present in this high-elevation, fog-dominated community. Nolana incana, however, is present, as are many 

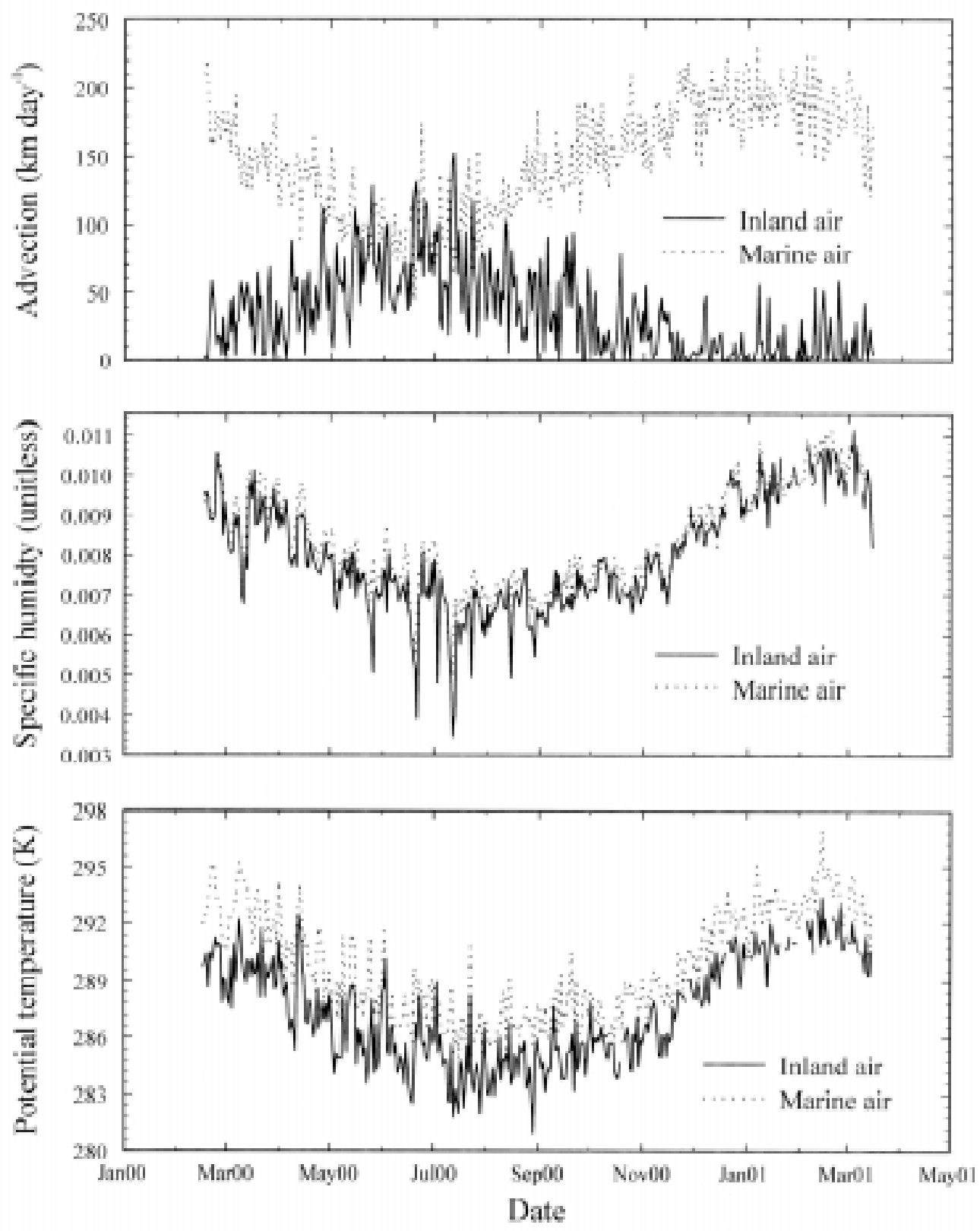

Fig. 10: Mean daily characteristics of the wind at the MET station. The first panel shows components of the total inland versus marine advection (in units of $\mathrm{km} \mathrm{day}^{-1}$ ) occurring along the adjusted $\mathrm{E}-\mathrm{W}$ axis (see Fig. 8). The second shows the specific humidity (i.e., the fraction of air that is water vapor, normalized by temperature) of the air broken down by whether that air is arriving in a westerly (marine) or easterly (inland) wind. The third shows the potential temperature of the air, again broken down by whether that air is arriving from the east or the west. Mean values of specific humidity and potential temperature are found by weighting with the component of the wind speed vector occurring along the adjusted E-W axis (see Fig. 8). Marine air is consistently warmer and moister than inland air. The calculation of specific humidity and potential temperature are described in the text.

Características medias diarias del viento cerca de la estación MET. El primer panel muestra los componentes del viento interior y marítimo a lo largo del eje este-oeste (vea Fig. 8). El segundo muestra la humedad específica (i.e., la proporción del aire que es vapor de agua, normalizada por temperatura) del aire separada por si viene del oeste (viento marítimo) o del este (viento interior). El tercero muestra la temperatura potencial del aire, también separada por la dirección, este u oeste. Los promedios de humedad específica y temperatura potencial se calcularon usando solo el componente del viento registrado a lo largo del eje este-oeste (vea Fig. 8). El aire marítimo es consistentemente más caliente y húmedo que el aire del interior. Los cálculos de la humedad específica y temperatura potencial se describen en el texto. 

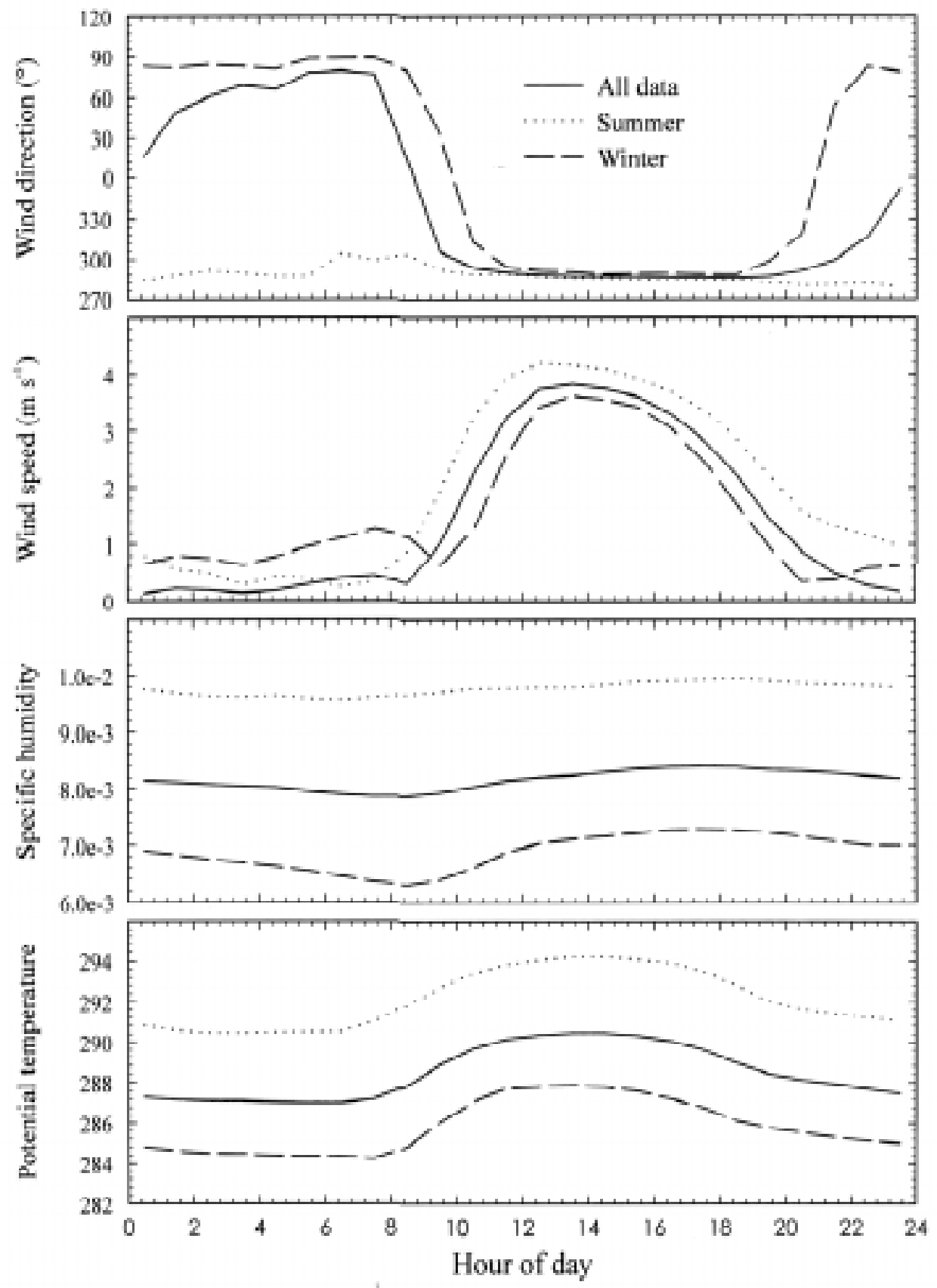

Fig. 11: Mean diurnal wind direction, wind speed, specific humidity and potential temperature at the MET station, shown on a hourly basis. Shown are the mean values of each for the entire measurement period, for the summer months (summer solstice to autumnal equinox), and for the winter months (winter solstice to vernal equinox). Mean wind direction and speed are calculated by averaging for each hour the easterly and northerly components of each measured wind speed vector during that hour on all days of the measurement period. Mean specific humidity and potential temperature are found by weighting each measurement by the advection (speed times time) measured for each hour.

Promedios diurnos de la dirección, velocidad, humedad específica, y temperatura potencial del aire en la estación MET para cada hora, durante el verano (la época entre el solsticio de verano y el equinoccio de otoño) e invierno (entre el solsticio de invierno y el equinoccio de primavera). La dirección media y velocidad media del viento se calcularon como promedios en cada hora usando los componentes del viento del norte y del este durante esa hora durante todos los días del período en que se registró el viento. Los promedios de la humedad específica y la temperatura potencial se calcularon ponderando cada medición por la advección (velocidad por tiempo) medida cada hora. 
of the low-density Nolana species found in the arroyo, such as $N$. divaricata and $N$. leptophylla.

Note that one of the more abundant species in Quebrada Agua Salada, Ophryosporus triangularis, showed a sharp decline in density at elevations above $250 \mathrm{~m}$, but its distribution within the transects was extremely patchy and clumped and it is possible that the arbitrary placement of the transects could mislead as to the actual abundance as a function of elevation. Thus, we have omitted it.

\section{DISCUSSION}

\section{Inversion layer stability}

The high temperature, low humidity excursions observed in the winter at the high elevation stations suggests strongly that during the winter months the inversion layer either drops below station elevation, or disintegrates entirely. The latter is less likely, since wholesale disruption of the inversion layer would entrain humid air from lower elevations, and the atmosphere during these excursions is quite dry; moreover, low-humidity excursions at low-elevation sites would have been observed as well, and they were not. More likely, the inversion layer subsides during the winter, below the level of the high-elevation sites (LOM, UQA). Thus, an addendum to some of the reports stating the increased strength of the inversion layer and resulting camanchaca during the winter (Trewartha 1981, Rundel et al. 1991, Rundel et al. 1996 ) is in order. True, the winter camanchaca is more intense, but it is also shallower. Plants at high elevations are thus exposed to far higher VPDs during the winter, in contrast to the low elevation sites, such as the LQA station, where VPDs are lowest in the winter.

The subsidence of the inversion during the winter is due to weakening in the onshore breeze so prevalent during other parts of the year. During the summer months, sea-surface temperatures and evaporation are at their highest, as is heating of the surface of the inland desert, leading to an increase the rate of advection of cool, moist air over the desert. Because it is more buoyant than the air below, drier air above prevents convection and cumulus formation. The height of the inver-

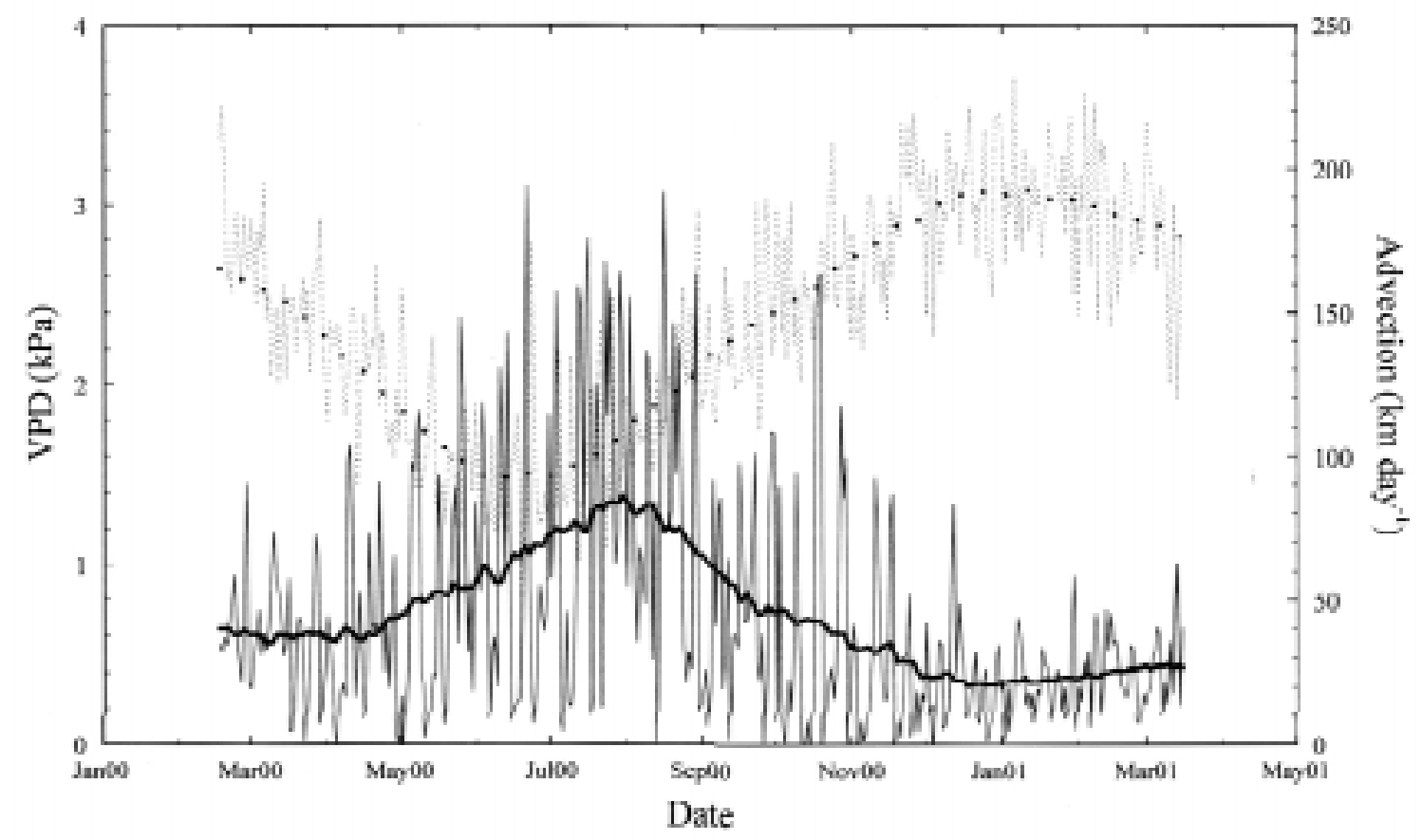

Fig. 12: Maximum daily vapor pressure deficit at the LOM station against westerly advection at the MET station from mid-February, 2000, to mid-March, 2001. Shown are VPD (kPa, thin solid line), VPD following application of a 61-day running mean filter (thick solid line), advection (km day ${ }^{-1}$, thin dotted line), and advection following application of a 61-day running mean filter (thick dotted line).

Relación entre el déficit de presión de vapor (VPD) máximo y diario del aire en la estación LOM y la advección del oeste en la estación MET, entre mediados de febrero de 2000 y mediados de marzo de 2001. Se muestra el VPD (kPa, línea angosta), el promedio parcial de 61 días del VPD (línea ancha), la advección ( $\mathrm{km} \mathrm{día}^{-1}$, línea angosta de puntos), y el promedio parcial de 61 días de la advección (línea ancha de puntos). 

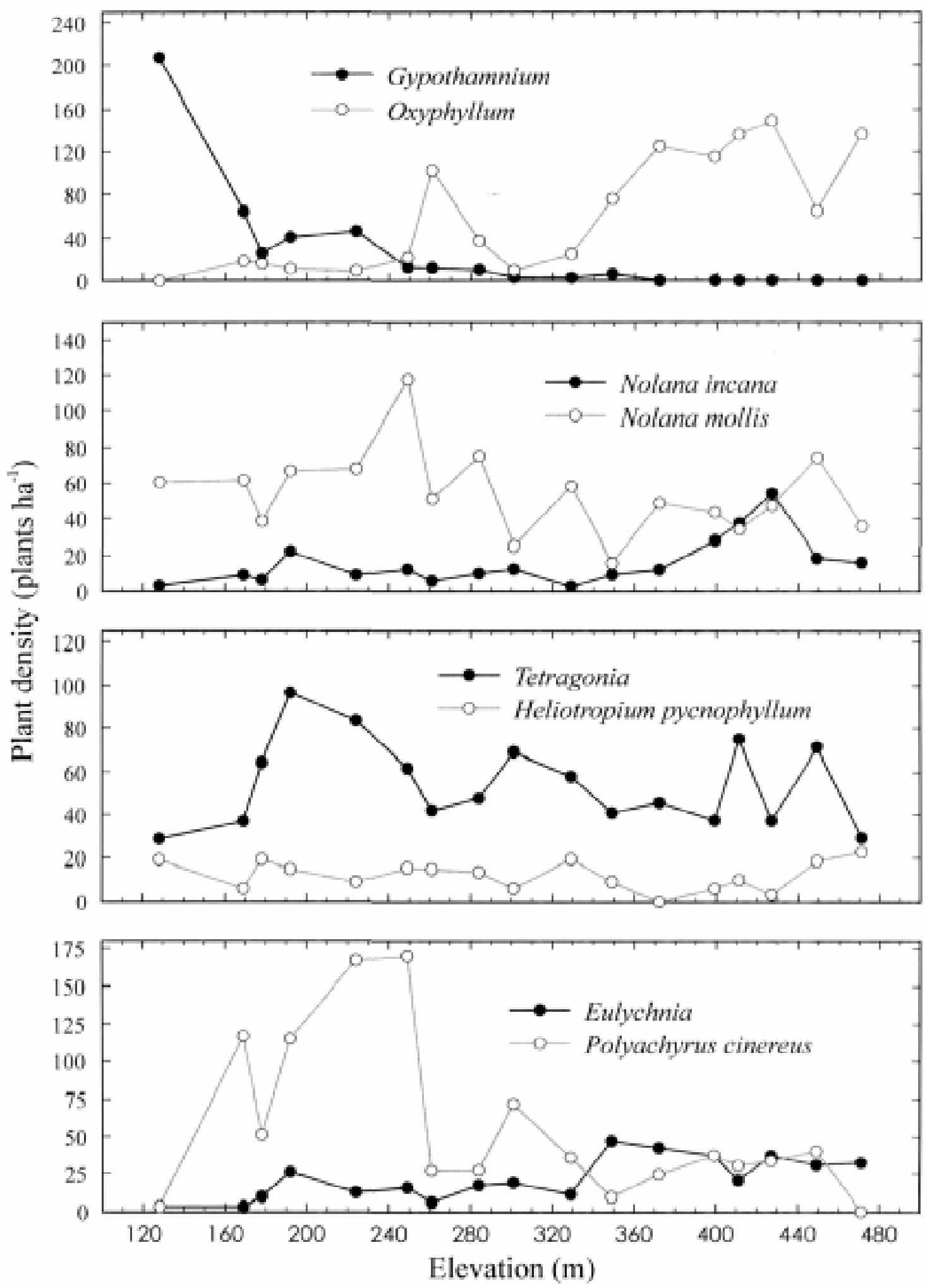

Fig. 13: Plant density $(\mathrm{n}=1)$ of eight perennial plant species in Quebrada Agua Salada as a function of elevation.

Densidad vegetal $(n=1)$ de ocho especies de plantas perennes contra altitud en Quebrada Agua Salada. 
sion layer then depends on the quantity of marine air brought across the coastline (Fig. 12), and on the heat and moisture content of the overlying air.

Whereas previously the inversion layer and resulting camanchaca were considered a perennial and vital component of plant life at high elevations, and while these climatic components are still present throughout the year, they are by no means a persistent feature during the winter months. Two important features, then, distinguish high-elevation sites in Pan de Azúcar from lowelevation sites: persistent high-humidity and fog throughout most of the year, and occasionally high VPDs during the winter. The benefit to plant life in low elevation sites is therefore a consistently low annual VPD. Thus, the atmosphere may not saturate, but it seldom reaches the opposite dry extreme observed some winter days at high elevation.

\section{Precipitation and local relief}

The distribution of precipitation in the park appears fairly uniform, with some local variation due to forced topographical convection, but without extensive pluviometer installations it is impossible to know for certain. Though its interception may be even, the effect of precipitation is highly heterogeneous, as rain often fails to penetrate very deeply into the dry mineral soils of the park and will collect in the system of bajadas and arroyos that eventually lead to the sea. Most of the vegetation in the park is concentrated in dry waterways and in the high elevation lomas, where fog is a common climatic component. Interior sites also receive rain, but local relief is not sufficiently developed to concentrate runoff to the extent necessary for the establishment of plant communities. Moreover, incoming solar radiation is sufficiently high in those sites, due to the weakened state of the inversion that far inland, to enhance rates of latent heat flux.

Low elevation arroyo communities may have another advantage over their high-elevation lomas counterparts (in addition to persistently low VPDs). The local topology of the arroyos concentrate runoff to an extent not found in the lomas. As such, plants growing in the arroyos may receive effectively more precipitation than sites that do not benefit from high runoff concentration.

\section{Community composition}

The elevation gradient in plant species density in Quebrada Agua Salada suggests that there may be some relation between the climates found at the extremes of the arroyo and the physiological traits of those species. No manipulative study was performed, so little can be done other than to speculate. However, it is reasonable to suspect that these trends represent clear bounds to the distribution of Gypothamnium pinifolium and Oxyphyllum ulicinum, and that certain cacti, such as Eulychnia saint-pieana are more abundant at high than at low-elevation sites. At this time it is difficult to say what climatic conditions bear on these trends, yet it would be fair to say that the winter-time subsidence of the inversion layer at high elevations may be an important factor. If so, sensitivity to change in the marine inversion layerdominated climate pattern currently prevalent over the park could have an impact on the community composition and distribution of many of the park's arroyos, whether that change made the inversion stronger or weaker.

Other changes might be expected following on changes in the pattern of precipitation in the park. Because rainfall is not only limited in this region, but also sporadic, it is difficult to say what effect an increase or decrease in local rainfall would have without also knowing whether that change was the result of a shift in frequency or magnitude. For instance, arroyo and bajada plant communities may be buffered from the infrequency of precipitation by the fact that so much of that rainfall is concentrated in seeping runoff immediately after its occurrence. Nevertheless, community composition in all sites in the park should be expected to change should rainfall increase.

Different sites in the park are to some extent florally distinct. Communities in the high-elevation fog-zone near the LOM station entirely lack a number of species present in arroyo communities, most notably Oxyphyllum ulicinum, Polyachyrus cinereus, Gypothamnium pinifolium, and Nolana mollis. Moreover, a number of species found near the LOM station, such as various showy species of Nolana, are entirely absent from the arroyo communities. The limits set on the distributions of these species may be in part due to these species' relative competitive advantages in their respective climates, which may in turn be the result of subtle differences between the lowelevation species, which can survive in the drier, low-elevation sites but require high and persistent atmospheric humidity, and their high-elevation counterparts, which receive copious amounts of surface dew from the fog, but are exposed to extremely high VPDs during the winter months. Nolana mollis and N. flaccida, for instance, two species that excrete salt from their glands in their leaf surfaces to condense water out of the atmo- 
sphere, may have no special advantage at a high elevation site, but may benefit considerably from the consistently high, but never quite saturated, humidity of the low-elevation sites.

The limited community diversity of the park interior, as near the INT station, is most likely controlled by the lack of fog, the rapid drying of precipitation, and the minimal degree of runoff concentration due to shallow relief. Nevertheless, some species persist, notably $N$. flaccida, which has the capacity to condense water out of the atmosphere to keep its leaves moist, as does N. mollis in Quebrada Agua Salada and other parts of the park.

Considerably more work is required to conclusively determine the causal relations between climate and plant species distributions. This work, however, descriptive though it may be, provides a starting point for analysis of these relations and thus a means for local assessment of the potential changes that could be expected under various climate change scenarios. The Atacama and Peruvian deserts are old and very stable, but even small changes in the daily and seasonal establishment of the marine inversion layer, or alterations in the ENSO cycle, could have dramatic effects on Pan de Azúcar's vegetation.

\section{CONCLUSIONS}

In Parque Nacional Pan de Azúcar, in the Atacama desert of Chile, winter-time weakening in onshore advection leads to a drop in the altitude of the marine inversion layer, which in turn causes high-temperature, low-humidity excursions at high-elevation sites. This feature, in tandem with the nearly perennial fog, is an important climatic component of high-elevation regions of the coastal range. In contrast, at the low-elevation sites, atmospheric humidity is relatively constant yearround and is not subject to large excursions, though it may never reach saturation. Climatic changes in the Southern Pacific, such as small changes in the direction or intensity of the trade winds or shifts in the southerly Humboldt Current, could alter the elevational distribution of plants in such sites as Quebrada Agua Salada, where species present at low elevation are entirely absent at high elevation, and vice versa. Certain species common to the arroyo communities, such as Nolana mollis, which excretes salt through specialized leaf glands to condense water out of the atmosphere, would have little to no advantage in the high elevation sites where persistent fog would obviate the need for its special leaf adaptation. Conversely, those species common at high eleva- tion but absent at low elevation could rely for their survival on the constant drip provided by the fog, and maintain their physiological integrity during the occasional hot and dry winter on stored water in the soil or their own tissues. This study is one of the first to look at local correlations between climate and plant species distribution in the lomas of Chile, and more of its kind are necessary in such heterogeneous ecosystems if we wish to begin to adequately assess the potential impact of climate change on the Peruvian/ Atacama coastal lomas flora. Currently, no predictions can be made as to the increase or decrease of local floral, as our data set only covers a short period of time.

\section{ACKNOWLEDGEMENTS}

We are grateful for the support of the Corporación Nacional Forestal (CONAF) of Chile, and particularly for that of the administrator of Parque Nacional Pan de Azúcar, Ibar Páez Lara, and numerous other park guards, especially Nivaldo Castillo, Alfonso Sepúlveda, and Jorge Vega, in their patient assistance in climate data collection. We are indebted to Melanie Gómez Waring, Stephanie Stuart, José Rojas, and Claudio Ramírez for invaluable field assistance. We also wish to thank the administration of Universidad de Las Américas in Santiago for their support and assistance in the transportation of equipment to and from the field. We also thank Michael Dillon for assistance in plant identification, and Michael Dillon, Randol Villalobos Vega, and one anonymous reviewer for careful review of the manuscript. This research was funded under a US National Science Foundation grant to Harvard University (INT-9901329), with assistance from the David Rockefeller Center for Latin American Studies and the Department of Organismic and Evolutionary Biology, both at Harvard University.

\section{LITERATURE CITED}

ALMEYDA E (1948) Pluviometría de las zonas del desierto y las estepas cálidas de Chile. Universidad de Chile, Santiago, Chile. 167 pp.

DILLON MO \& AE HOFFMANN. (1997) Lomas formations of the Atacama desert, northern Chile. In: Davis SD, VH Heywood, O Herrera-McBryde, J Villa-Lobos \& AC Hamilton (eds) Centres of plant diversity, a guide and strategy for their conservation: 528-535. World Wildlife Federation, Information Press, Oxford, United Kingdom. 
DILLON MO \& PW RUNDEL (1989) The botanical response of the Atacama and Peruvian desert floras to the 1982-1983 El Niño event. In: Glynn PW (ed) Global ecological consequences of the 1982-1983 El Niño-southern oscillation: 487-504. Elsevier, New York, New York, USA.

EHLERINGER JR, HA MOONEY, PW RUNDEL, RD EVANS, B PALMA \& J DELATORRE (1992) Lack of nitrogen cycling in the Atacama desert. Nature 359: 316-318.

EHLERINGER JR, PW RUNDEL, B PALMA \& HA MOONEY (1998) Carbon isotope ratios of Atacama desert plants reflect hyperaridity of region in northern Chile. Revista Chilena de Historia Natural 71: 7986.

EVANS RD \& JR EHLERINGER (1994) Plant $\underline{d}^{15} \mathrm{~N}$ values along a fog gradient in the Atacama desert, Chile. Journal of Arid Environments 28: 189-193.

HAJEK ER \& F DI CASTRI (eds) (1975) Bioclimatografía de Chile. Dirección de Investigación Vice-Rectoría Académica Universidad Católica de Chile, Santiago, Chile. 107 pp.

HARTMANN DL (1994) Global physical climatology. Academic Press, San Diego, California, USA. 411 pp.

Associate Editor: Julio Gutiérrez

Received September 7, 2001; accepted December 11, 2002
JOHNSTON IM (1929) I. Papers on the flora of northern Chile: 1. The coastal flora of the departments of Chañaral and Taltal. Contributions from the Gray Herbarium of Harvard University 85: 1-138.

MOONEY HA, SL GULMON, J EHLERINGER \& PW RUNDEL (1980) Atmospheric water uptake by an Atacama desert shrub. Science 209: 693-694.

RICHARDS JM (1971) Simple expression for the saturation vapor pressure of water in the range of -50 degrees to 140 degrees. British Journal of Applied Physics 4: L15-L18.

RUNDEL PW, MO DILLON \& B PALMA (1996) Flora and vegetation of Pan de Azúcar National Park in the Atacama desert of northern Chile. Gayana Botánica (Chile) 53: 295-315.

RUNDEL PW, MO DILLON, B PALMA, HA MOONEY, SL GULMON \& JR EHLERINGER (1991) The phytogeography and ecology of the coastal Atacama and Peruvian deserts. Aliso 13: 1-49.

TAGO-NAKAZAWA M \& MO DILLON (1999) Biogeografía y evolución del caldo Nolana (NolanaeaSolanaceae). Arnaldoa 6: 81-116.

TREWARTHA GT (1981) The earth's problem climates. University of Wisconsin Press, Madison, Wisconsin, USA. 371 pp. 